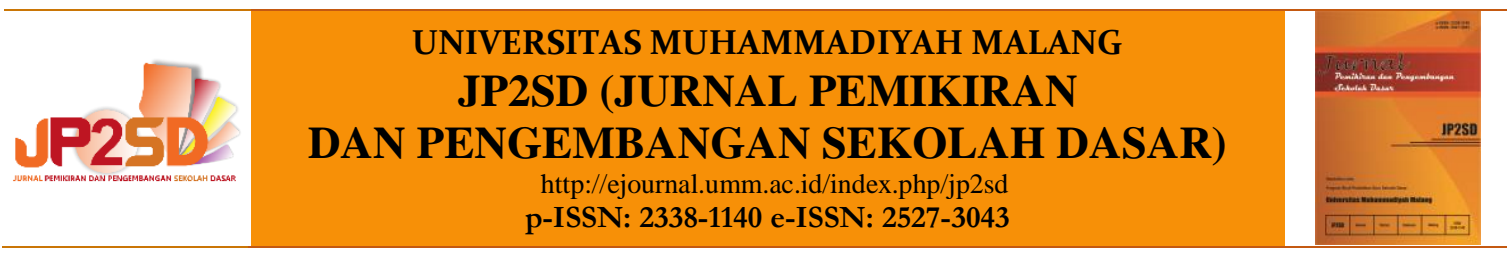

\title{
Kemampuan Representasi Piktorial Operasi Hitung Pecahan pada Mahasiswa Pendidikan Guru Sekolah Dasar
}

\author{
Wulida Arina Najwa \\ STKIP Al Hikmah, Indonesia \\ najwaarina@gmail.com
}

\begin{tabular}{ll}
\hline INFORMASI ARTIKEL \\
\hline Riwayat: & \\
Diterima & 20 Januari \\
& 2020 \\
Revisi & 8 Maret \\
& 2020 \\
Dipublikasikan & 26 April \\
& 2020
\end{tabular}

Kata kunci:

Representasi, pictorial, operasi hitung, pecahan.

\begin{abstract}
ABSTRAK
Siswa sekolah dasar rata-rata berumur 7-12 tahun, berdasarkan teori Piaget termasuk dalam tahap operasional konkret. Siswa pada tahap tersebut lebih mudah memahami materi yang konkret, salah satunya menggunakan gambar. Mahasiswa calon guru sekolah dasar sudah seharusnya menguasai materi sekolah dasar berdasarkan tahap perkembangan siswanya. Salah satu materi sekolah dasar yang sering dianggap sulit adalah pecahan. Sehingga pembelajaran pecahan membutuhkan bantuan berupa gambar untuk memudahkan siswanya. Penelitian ini menggunakan penelitian kualitatif yang mendeskripsikan kemampuan representasi piktorial mahasiswa calon guru sekolah dasar. Hasil penelitian ini menunjukan bahwa kemampuan representasi mahasiswa calon guru sekolah dasar sangat beragam. Tidak semua mampu merepresentasikan operasi hitung pecahan dengan tepat.
\end{abstract}

\section{ABSTRACT}

Keywords:

Representation, fractions, student teacher candidates

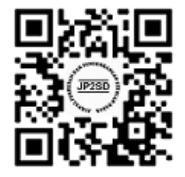

Copyright (C) 2020, Wulida Arina Najwa

This is an open access article under the CC-BY-SA license

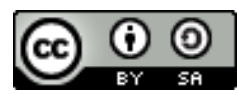

Elementary school students on average aged $7-12$ years, based on Piaget's theory are included in the concrete operational stage. Students at this stage more easily understand concrete material, one of which uses pictures. Prospective elementary school teacher students should have mastered primary school material based on the stage of development of their students. One of the elementary school materials that is often considered difficult is fractions. So that learning fractions requires help in the form of images to facilitate their students. This study uses qualitative research that describes the pictorial ability of students' representation of prospective elementary school teachers. The results of this study indicate that the ability of representation of prospective elementary school teacher students is very diverse. Not all are able to represent fractional counting operations correctly. 
How to cite: Wulida Arina Najwa. (2020). Kemampuan Representasi Piktorial Operasi Hitung Pecahan pada Mahasiswa Pendidikan Guru Sekolah Dasar. Jurnal Pemikiran dan Pengembangan Sekolah Dasar, Vol 8 No 1, 19-26. doi: https://doi.org/10.22219/jp2sd.v8i1.11020

\section{PENDAHULUAN}

Matematika sebagai ilmu abstrak harus direpresentasikan agar mudah dipahami dan dipelajari. NCTM (2000) menuliskan bahwa representasi sebagai kunci dalam mempelajari matematika. Ide matematika dapat direpresentasikan dalam berbagai cara seperti gambar, tabel, grafik, simbol, bilangan, dan sebagainya. Representasi dari ide matematika tersebut menjadi dasar bagaimana seseorang memahami dan menggunakan ide matematika. Garderen, Scheuermann, Poch, \& Murray (2018) menyatakan representasi membantu siswa dalam memahami masalah matematika dan memudahkan dalam menyelesaikanya. Dalam pelaksanaan pembelajaran, diharapkan dapat memfasilitasi siswa dalam mengembangkan standar representasi menurut NCTM (2000) yaitu: (1) membuat dan menggunakan representasi untuk mengkomunikasikan ide matematika, (2) memilih dan melakukan translasi pada berbagai representasi untuk memecahkan masalah, (3) menggunakan representasi untuk memodelkan, menafsirkan permasalahan matematika. Berdasarkan tiga standar tersebut, dapat disimpulkan bahwa merepresentasikan merupakan suatu kegiatan memodelkan permasalahan berdasarkan pemikiran siswa melalui cara yang berbeda-beda.

Ada dua sistem representasi yaitu representasi internal dan representasi eksternal (Goldin, 2003). Representasi internal merupakan sistem yang ada dalam pikiran terkait pemahaman konseptual dan prosedural. Sedangkan representasi eksternal diartikan sebagai hasil penuangan dari representasi internal. Karena representasi internal yang dimiliki seseorang berbeda-beda, maka representasi ekstrenal yang ditunjukkan setiap individu sangat dimungkinkan berbeda-beda (Villegas, Castro, \& Gutiérrez, 2009). Selain itu, representasi internal tidak bisa kita lihat secara langsung sehingga kemampuan representasi bisa dilihat berdasarkan representasi eksternalnya (Huinker, 2015). Siswa sekolah dasar masih dalam tahap operasional konkret sehingga membutuhkan representasi sebagai jembatannya. Jika siswa sekolah dasar membutuhkan hal itu, guru sudah selayaknya mengakomodasi dengan memberikan pembelajaran yang sesuai. Oleh karena itu, mahasiswa calon guru harus menguasai representasi materi matematika sekolah dasar. Berdasarkan penelitian awal yang dilakukan peneliti, pecahan merupakan salah satu materi sekolah dasar yang dianggap rumit oleh mahasiswa calon guru. Banyak diantara mereka belum memahami secara utuh pecahan dan operasi hitungnya dalam bentuk gambar. Berdasarkan uraian di atas, peneliti akan mengadakan penelitian terkait Kemampuan Representasi Piktorial Mahasiswa Calon Guru Sekolah Dasar pada Operasi Hitung Pecahan. Salah satu pentingnya penelitian ini yaitu agar mahasiswa calon guru sekolah dasar bisa merancang pembelajaran matematika yang sesuai dengan perkembangan kognitif siswa sekolah dasar.

\section{METODE}

Penelitian ini menggunakan pendekatan kualitatif yang mendeskrispsikan kemampuan representasi piktorial mahasiswa calon guru sekolah dasar pada operasi hitung pecahan. Subjek penelitian ini dipilih berdasarkan tingkat semester yang paling tinggi, yaitu semester lima. Dari mahasiswa semester lima kemudian diberikan beberapa soal pecahan yang selanjutnya diambil 3 mahasiswa. Tiga mahasiswa kemudian di 
wawancara untuk konfirmasi hasil pekerjaannya. Subjek penelitian tersebut diantaranya AP, dan LR masing-masing dari hasil pekerjaan yang paling banyak dikerjakan oleh mahasiswa.

Setelah mendapatkan subjek penelitian, peneliti memberikan beberapa soal pecahan yang akan diselesaikan menggunakan gambar. Jika hasil pekerjaan mahasiswa sudah didapatkan, maka peneliti akan melakukan wawancara terhadap ketiga subjek tersebut. wawancara diperlukan untuk memperjelas proses penyelesaian soal yang diberikan, sehingga tidak ada salah tafsir dari peneliti terhadap hasil pekerjaan subjek karena semua hasil pekerjaan subjek telah di konfirmasi. Soal pecahan yang diberikan peneliti diantaranya:

Selesaikan pecahan berikut menggunakan gambar!

Tabel 1. Soal pecahan

\begin{tabular}{cc}
\hline Soal & Jawab \\
\hline$\frac{1}{2}+\frac{1}{4}$ \\
\hline $2 \frac{1}{2}-1 \frac{1}{4}$ \\
$3 \times \frac{1}{2}$ \\
\hline$\frac{1}{2}: \frac{1}{4}$
\end{tabular}

Ketika hasil tes dan hasil wawancara sudah didapatkan, peneliti menganalisis data, mereduksi data, dan menyajikan data. Analisis pekerjaan mahasiswa dilakukan berdasarkan indikator-indikator berikut:

Tabel 2. Indikator Representasi Piktorial

\begin{tabular}{cl}
\hline No & \multicolumn{1}{c}{ Indikator } \\
\hline 1 & Menyajikan kembali data dari suatu masalah dalam bentuk gambar \\
\hline 2 & Menggunakan gambar untuk menyelesaikan masalah \\
\hline 3 & Membuat gambar untuk menunjukkan hasilnya \\
\hline
\end{tabular}

\section{HASIL DAN PEMBAHASAN}

Kemampuan representasi piktorial mahasiswa calon guru sekolah dasar dapat dilihat pada tabel 2 berikut.

Tabel 3. Kemampuan Representasi Piktorial Mahasiswa Calon Guru Sekolah Dasar

\begin{tabular}{clcc}
\hline \multirow{2}{*}{ No } & \multicolumn{1}{c}{ Indikator } & \multicolumn{2}{c}{ Subjek } \\
\cline { 3 - 4 } & \multicolumn{1}{c}{ LR } & AP \\
\hline 1 & $\begin{array}{l}\text { Menyajikan kembali data dari suatu masalah dalam } \\
\text { bentuk gambar }\end{array}$ & $\sqrt{ }$ & $\sqrt{ }$ \\
\hline 2 & Menggunakan gambar untuk menyelesaikan masalah & $\sqrt{ }$ \\
\hline 3 & Membuat gambar untuk menunjukkan hasilnya & $\sqrt{ }$ & $\sqrt{ }$ \\
\hline
\end{tabular}

Catatan: Bagian yang dicentang adalah indikator yang dipenuhi oleh subjek

Tiga subjek penelitian menunjukan kemampuan representasi piktorial mahasiswa calon guru SD yang berbeda-beda. Subjek LR melakukan representasi piktorial pada pecahan dengan sangat baik yang ditandai dengan terpenuhinya semua indikator. Sedangkan subjek AP membuat representasi piktorial pecahan dengan cukup baik yang ditandai dengan terpenuhinya 2 indikator. Berikut hasil pekerjaan LR terhadap soal yang diberikan. 
Tabel 4. Hasil Pekerjaan LR

\begin{tabular}{c}
\hline Soal \\
\hline$\frac{1}{2}+\frac{1}{4}$ \\
\hline $2 \frac{1}{2}-\mathbf{1} \frac{1}{4}$ \\
$3 x \frac{1}{2}+\square=\square=\square$ \\
\hline$\frac{1}{2}: \frac{1}{4}$ \\
\hline$\square+\square=\square$
\end{tabular}

Semua hasil pekerjaan LR menunjukkan bahwa rerpesentasi piktorial yang digunakan untuk menyelesaikan soal yaitu segi empat. Ada yang menggunakan persegi dan persegi panjang. Menurut Tyas \& Sujadi (2016) setiap orang bisa menggunakan representasi piktorial yang berbeda-beda dalam mengkonstruksi pengetahuannya. Hal ini sesuai dengan LR merepresentasikan pecahan menggunakan bentuk yang berbeda-beda.

Pada soal nomor satu tentang penjumlahan pecahan LR menggunakan persegi sebagai representasi pecahan. Mulanya ia membuat persegi yang dibagi menjadi 4 bagian dan diarsir 2 bagiannya yang menunjukkan pecahan $\frac{2}{4}$. Heruman (2012) menyatakan bahwa pecahan merupakan bagian dari suatu keutuhan. Bagian yang dimaksud tersebut adalah bagian yang ditandai dengan suatu arsiran. Kemudian pada pecahan yang kedua, LR sudah memahami bahwa 2/4 sama dengan $\frac{1}{2}$ sehingga ia langsung membuat persegi dengan 4 bagian kemudian salah satu bagiannya diarsir. Menurut Badaruddin (2016) yang dilakukan LR tersebut merupakan bagian dari proses pecahan yaitu menyamakan penyebut. Dari kedua ilustrasi tersebut kemudian LR menjumlahkan banyaknya bagian yang diarsir yaitu ada 3. Sehingga pada jawaban akhir ia menggambarkan 1 persegi dengan 4 bagian dan 3 bagian diataranya diarsir yang menunjukkan $\frac{3}{4}$ sebagai hasil.

Tidak jauh beda dengan penyelesaian nomor satu, LR menyelesaikan soal nomor 2 dengan menggunakan persegi yang dibagi menjadi 4 bagian. Gambar pertama menunjukkan soal $2 \frac{1}{2}$ yang diilustrasikan dengan dua persegi yang seluruhnya diarsir penuh dan satu persegi yang diarsir dua bagiannya. Kemudian setelah membubuhkan tanda "-" ia merepresentasikan $1 \frac{1}{4}$ dengan menggambar satu persegi yang diarsir secara utuh dan satu persegi yang diarsir satu bagiannya saja. Untuk menyelesaikan soal tersebut, LR mengurangi banyaknya arsiran pada gambar pertama dengan gambar kedua. Nurlita, Zubainur, \& Ahmad (2016) menjelaskan bahwa cara mengurangi pecahan bisa dilakukan dengan 2 cara, yaitu dengan mengurangi bilangan yang utuh terlebih dahulu kemudian mengurangi bilangan pecahan. Cara kedua dengan mengubah pecahan campuran ke pecahan biasa terlebih dahulu baru dikurangi. Sisa dari banyaknya arsiran tersebut merupakan hasilnya. LR mendapatka sisa arsiran sebanyak 5 sehingga ia menggambarkan 2 persegi dimana 1 keseluruhan perseginya di arsir sedangkan 1 persegi lainnya diarsir salah satu bagiannya saja. Sehingga didapatkan kelima bagian perseginya diarsir.

Berbeda dengan nomor satu dan dua, pada nomor tiga LR memahami perkalian sebagai penjumlahan berulang. Hal ini sesuai dengan Park \& Nunes (2001) bahwa 
perkalian dapat diartikan sebagai penjumlahan berulang. Oleh karena itu, ketika menjawab ia langsung menggambarkan representasi pecahan $\frac{1}{2}$ sebanyak tiga dan menghubungkannya dengan tanda jumlah. LR menggunakan prinsip penjumlahan pecahan tersebut untuk menyelesaikan hasil perkalian menggunakan gambar. Selanjutnya ia membuat representasi penyelesaiannya yaitu sebanyak tiga arsiran pada 2 persegi panjang. Sehingga dapat disimpulkan bahwa $3 \times \frac{1}{2}$ sama dengan $1 \frac{1}{2}$.

Pada soal pembagian pecahan $\frac{1}{2}: \frac{1}{4}$, LR mengerjakan dengan cara mundur. Menurut Bentley \& Bossé (2018) cara mundur digunakan karena subjek hanya memahami secara prosedural, tidak secara konseptual. Temuan ini dapat dilihat dari hasil pengerjaan dan hasil wawancara dengan LR. Ia menggambar pecahan $\frac{1}{4}$ dengan persegi panjang dengan 4 bagian yang salah satunya diarsir. Kemudian satu arsiran tersebut dibagi $\frac{1}{2}$ sesuai dengan soal sehingga hasil dari $\frac{1}{2}: \frac{1}{4}$ adalah 2. Ketika dilakukan wawancara, LR menjelaskan bahwa ia mengerjakan mundur karena untuk mengerjakan pembagian pecahan harus membalik pecahan yang belakang dan mengganti tanda dengan perkalian. Mindset yang dimiliki mahasiswa tersebut menurut Olufemi \& Adediran (2018) dikarenakan pengajaran disekolah yang cenderung sistematis, dengan mengabaikan pemahaman siswa terhadap makna pembagian pecahan.

Tabel 5. Hasil Pekerjaan AP

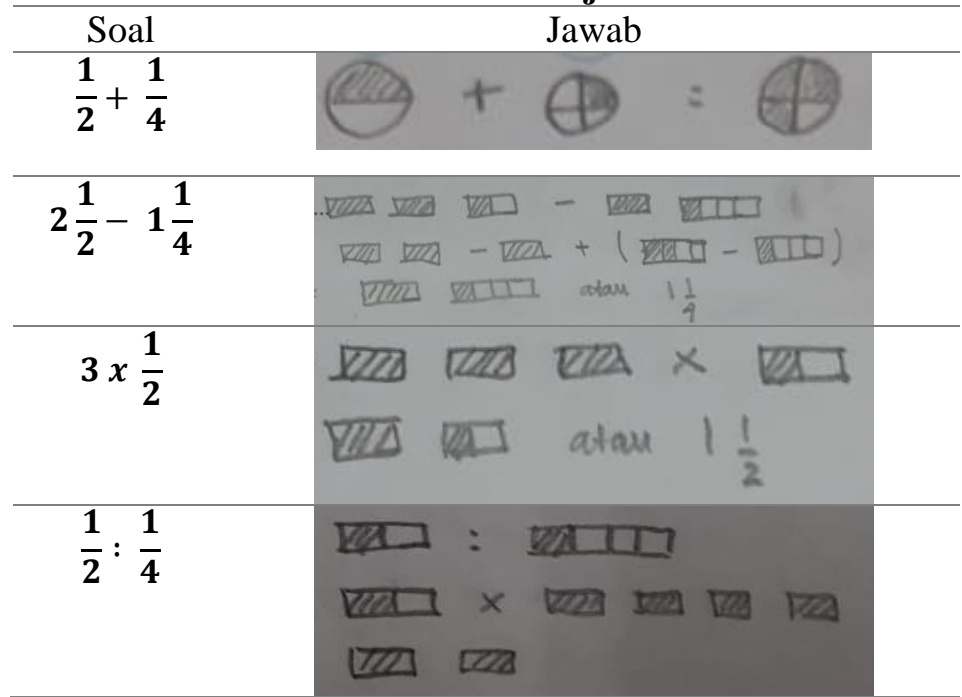

Berdasarkan hasil pekerjaan AP tersebut, dapat kita cermati bahwa penyelesaian soal pecahan menggunakan bentuk yang berbeda-beda. Hal ini dikarenakan setiap individu dapat membuat penyelesaian menggunakan gambar yang berbeda-beda (Tyas \& Sujadi, 2016). Nomor 1 AP menyelesaikan menggunakan lingkaran, sedangkan nomor 2 sampai nomor 4 menggunakan persegi panjang. Berdasarkan hasil wawancara, AP menggunakan lingkaran pada nomor 1 karena pecahannya cukup sederhana. Menurut Sidji (2017) pecahan yang berpenyebut 4 atau 2 dapat diselesaikan dengan bentuk lingkaran. Pertama-tama, AP menggambar lingkaran yang pertama dan memecah menjadi dua serta mengarsir salah satu bagiannya. Lingkaran pertama menunjukkan pecahan $\frac{1}{2}$. Sedangkan lingkaran kedua, AP membagi menjadi 4 bagian dan mengarsir salah satu bagiannya. Lingkaran tersebut menunjukkan pecahan $\frac{1}{4}$. Banyaknya bagian yang diarsir menunjukkan pembilang dan banyaknya bagian yang dipecah menunjukkan penyebutnya. 
Langkah berikutnya yang dilakukan oleh AP adalah menjumlahkan gambar pertama dengan gambar kedua. Gambar pertama yang hanya dibagi menjadi 2 kemudian diubah menjadi 4 bagian. Subjek yang menyamakan penyebut menggunakan gambar dengan menyamakan banyaknya bagian pecahan (Suarjana, Parmiti, \& Elma, 2018). Sehingga ada dua bagian yang diarsir untuk gambar pertama. Dapat dilihat bahwa gambar pertama dan gambar kedua sudah sama-sama dibagi menjadi 4 bagian. Setelah itu, AP menjumlahkan bagian yang telah diarsir dan didapatkan 3 daerah yang diarsir dari keseluruhan 4 bagian dan didapatkan hasil dari $\frac{1}{2}+\frac{1}{4}$ adalah $\frac{3}{4}$.

Berbeda dengan penyelesaian pada nomor 1, penyelesaian AP pada nomor 2 tidak lagi menggunakan lingkaran, melainkan dengan persegi panjang. Padahal jika ditinjau dari Sidji (2017) operasi pecahan yang berpenyebut 2 dan 4 dapat dengan mudah diselesaikan menggunakan gambar lingkaran. AP menggambarkan $2 \frac{1}{2}$ dengan menggambar 2 persegi panjang yang diarsir utuh dan 1 persegi panjang lagi yang dibagi menjadi 2 bagian dan diarsir salah satu bagiannya. Kemudian ia menggambarkan $1 \frac{1}{4}$ dengan membuat 1 persegi panjang yang diarsir utuh dan 1 persegi panjang yang dibagi menjadi 4 bagian serta mengarsir salah satu bagiannya. Dari 2 representasi yang dibuat oleh AP, ada beberapa hal yang perlu dicermati. Salah satunya pembuatan gambar persegi panjang oleh AP yang tidak konsisten, tidak semua persegi panjang besarnya sama terutama yang dibagi menjadi 4 persegi panjang lebih besar dari pada yang dibagi 2 maupun yang diarsir utuh. Padahal, persegi panjang tersebut merepresentasikan pecahan yang seharusnya bentuk dan besarnya sama. Menurut Dewanti (2018) ketidakkonsistenan subjek dalam menggambarkan pecahan salah satunya dipengaruhi oleh tingkat berfikir kritis subjek.

Setelah mengilustrasikan pecahan menggunakan gambar, AP mulai menyelesaikan soal dengan mengoperasikan pecahan dalam bentuk gambar tersebut. Mula-mula, AP mengurangkan pecahan yang diarsir penuh tersendiri dan pecahan yang tidak diarsir penuh sendiri. Berdasarkan penelitian Palpialy \& Nurlaelah (2016) rata-rata subjek menjumlahkan bilangan utuhnya terlebih dahulu kemudian menjumlahkan pecahannya. Namun, cara tersebut tidak berlaku untuk pecahan campuran yang pecahan pertamanya lebih kecil dari pada pecahan kedua (Nurlita et al., 2016)). Pada pecahan yang tidak diarsir penuh, AP mengubah pecahan $\frac{1}{2}$ yang awalnya di representasikan menggunakan persegi panjang yang dibagi dua bagian menjadi empat bagian. Pecahan pertama diarsir salah satu bagiannnya menjadi persegi panjang yang dibagi empat bagian dan diarsir dua bagiannya. Hasil pengurangan dari persegi panjang yang diarsir utuh menyisakan 1 persegi panjang. Sedangkan pengurangan persegi panjang yang tidak utuh menyisakan 1 persegi panjang yang dipecah 4 bagian dan diarsir salah satu bagiannya. Berdasarkan ilustrasi tersebut, AP menuliskan hasilnya yaitu $1 \frac{1}{4}$.

Pada soal nomor 3, AP mulai mengerjakan dengan mengilustrasikan 3 persegi panjang yang diarsir penuh. Kemudian setelah tanda perkalian, ia menggambarkan 1 persegi panjang yang dibagi menjadi 2 bagian dan diarsir pada salah satu bagiannya sehingga menunjukkan pecahan $\frac{1}{2}$. Berdasarkan hasil wawancara dengan AP, setelah mengilustrasikan soal ia tidak menyelesaikan menggunakan gambar. Melainkan menghitung secara manual $3 \times \frac{1}{2}=3 / 2$ kemudian AP menggambar satu persegi panjang yang di arsir penuh dan satu persegi panjang yang dibagi menjadi 2 bagian dengan salah satu bagiannya diarsir. Hal ini menunjukkan bahwa AP menghitung secara prosedural 
untuk mendapatkan penyelesaian dari soal tersebut dan tidak menggunakan gambar sebagai media untuk menyelesaikan soal yang diberikan. Menurut Yudianto (2013) hal ini dikarenakan mahasiswa tidak memahami secara utuh perkalian pecahan, tetapi hanya mengetahui cara prosedural penyelesaiannya. Oleh karena itu, sangat penting membekali siswa dengan pemahaman yang utuh sehingga tidak terjadi miskonsepsi. Hal-hal seperti itu sering dijumpai pada siswa dan mahasiswa, sehingga mereka menganggap matematika hanya sebatas prosedur (Gradini, 2016).

Soal pada nomor terakhir tentang pembagian pecahan dikerjakan AP dengan cara yang hampir sama dengan nomor tiga. Ia mengerjakan dengan menyelesaikan secara prosedural yaitu dengan mengubah pembagian menjadi perkalian terlebih dahulu kemudian baru digambarkan setelah mendapatkan hasilnya. Hal ini diketahui dari hasil wawancara AP.

P: "Setelah menggambarkan ilustrasi sesuai dengan soal, bagaimana kamu menyelesaikan soal tersebut menggunakan gambar?" AP: "Saya belum terlalu paham terkait penyelesaian menggunakan gambar. Tetapi saya paham menyelesaikan dengan cara pembagian manual. Jadi saya hitung dulu pembagiannya baru saya gambar hasilnya"

Mahasiswa calon guru seharusnya memiliki pemahaman yang utuh terkait operasi pecahan. Sehingga ketika soal yang diberikan memerlukan penyelesaian prosedural maupun yang menguji pemahaman, keduanya bisa diselesaikan. Menurut Jamil (2018) miskonsepsi yang terjadi pada mahasiswa seharusnya diberikan scaffolding untuk perbaikan. Harapannya, pemahaman yang utuh tersebut dapat digunakan sebagai bekal mahasiswa calon guru ketika mengajar di sekolah (Warsono, 2017).

\section{SIMPULAN}

Hasil penelitian dan pembahasan di atas menunjukkan deskripsi kemampuan representasi piktorial mahasiswa calon guru sekolah dasar pada materi pecahan. Mahasiswa yang memenuhi semua indikator, menunjukan kemampuan representasi piktorial yang baik. Sedangkan mahasiswa yang belum memenuhi semua indikator, masih ditemukan beberapa ketidaktepatan dalam melakukan representasi piktorial pada pecahan. Dari hasil penelitian dan pembahasan yang dilakukan, peneliti mempunyai beberapa saran terkait penelitian yang akan datang. Perlu dilakukan penelitian terkait analisis ketidaktepatan mahasiswa dalam membuat representasi piktorial pada pecahan. Sebagai tindak lanjut dari analisis tersebut, scaffolding untuk memperbaiki ketidaktepatan representasi piktorial juga diperlukan sehingga penelitian menjadi lengkap. Terdapat penelitian yang menganalisis kemampuan representasi piktorial mahasiswa calon guru pada materi pecahan kemudian analisis ketidaktepatannya serta scaffolding yang harus diberikan untuk mengatasi ketidaktepatan tersebut.

\section{REFERENSI}

Badaruddin. 2016. Analisis Kesalahan dalam Menyelesaikan Soal-Soal Operasi Hitung Pecahan Pada Siswa Kelas VII SMP Negeri 10 Kendari. Jurnal Penelitian Pendidian Matematika, 4(2), 43-56.

Bentley, B., \& Bossé, M. J. 2018. College Students ' Understanding of Fraction Operations. International Electronic Journal of Mathematics Education, 13(3), 233-247.

Dewanti, S. S. 2018. Profil Berfikir Kritis Mahasiswa PGMI dalam Memecahkan 
Masalah Matematika Dasar. Jurnal Matematika Dan Pembelajaran, 6(1), 11-22. Garderen, D. Van, Scheuermann, A., Poch, A., \& Murray, M. M. 2018. Visual Representation in Mathematics: Special Education Teachers' Knowledge and Emphasis for Instruction. Teacher Education and Special Education, 41(1), 7-23. https://doi.org/10.1177/0888406416665448

Goldin, G. 2003. Representation in School Mathematics: A Unifying Research Perspective, (October).

Gradini, E. 2016. Miskonsepsi dalam Pembelajaran Matematika Sekolah Dasar Di Dataran Tinggi Gayo, III(2), 52-60.

Heruman. 2012. Model Pembelajaran Matematika. Bandung: Rosdakarya.

Huinker, D. 2015. Representational Competence: A Renewed Focus for Classroom Practice in Mathematics. Winconsin Teacher of Mathematics, 1-8.

Jamil, A. F. 2018. Pembelajaran Berbasis Scaffolding Untuk Mengurangi Miskonsepsi Aljabar Mahasiswa. JP3, 8(2), 615-623.

NCTM. 2000. Six Principles for School Mathematics.

Nurlita, Zubainur, C. M., \& Ahmad, A. 2016. Miskonsepsi Konsep Prasyarat Aljabar Mahasiswa Pendidikan Guru Madrasah Ibtidaiyah. Jurnal Didaktik Matematika, 3(2), 85-95.

Olufemi, O. T., \& Adediran, A. A. 2018. Factors Affecting Students' Academic Perfomance in College of Education in Southwest, Nigeria. British Journal of Education, 6(10), 43-56.

Palpialy, J. J., \& Nurlaelah, E. 2016. Pengembangan Desain Didaktis Materi Pecahan pada Sekolah Menengah Pertama ( SMP ). Jurnal Matematika Integratif, 11(2), 127-136.

Park, J., \& Nunes, T. 2001. The development of the concept of multiplication. Cognitive Development, 16, 763-773. https://doi.org/10.1016/S0885-2014(01)00058-2

Sidji, I. 2017. Penggunaan Gambar Luas Daerah Untuk Meningkatkan Pemahaman Siswa Terhadap Operasi Penjumlahan Bilangan Pecahan SD Kabupaten Bone. JIKAP PGSD: Jurnal Ilmiah Ilmu Kependidikan, 1(2), 162-173.

Suarjana, I., Parmiti, D. P., \& Elma, P. 2018. Analisis Kesulitan Siswa dalam Menyelesaikan Operasi Hitung Pecahan Siswa Sekolah Dasar. International Journal of Elementary Education, 2(2), 144-155.

Tyas, W. H., \& Sujadi, I. 2016. Representasi Matematatis Siswa dalam Menyelesaikan Masalah Matematika pada Materi Aritmatika Sosial dan Perbandingan Ditinjau dari Gaya Kognitif Siswa Kelas VII SMP Negeri 15 Surakarta Tahun Ajaran 2014/2015. Jurnal Elektronik Pembelajaran Matematika, 4(8), 781-792.

Villegas, J. L., Castro, E., \& Gutiérrez, J. (2009). Representations in problem solving: A case study with optimization problems Representations in problem solving : a case study with optimization problems, 7(1), 279-308.

Warsono. (2017). Guru: Antara Pendidik, Profesi, dan Aktor Sosial. The Journal of Society\&Media, 1(1), 1-10.

Yudianto, E. (2013). Profil pengetahuan konseptual dan pengetahuan prosedural siswa dalam mengidentifikasi masalah pecahan. AdMAthEdu, 3(1), 27-36. https://doi.org/10.12928/admathedu.v3i1.4830 